Maurer School of Law: Indiana University

Digital Repository @ Maurer Law

1927

\title{
Some Conflicting Decisions of the United States Supreme Court
}

Hugh Evander Willis

Indiana University School of Law - Bloomington

Follow this and additional works at: https://www.repository.law.indiana.edu/facpub

Part of the Constitutional Law Commons, and the Courts Commons

\section{Recommended Citation}

Willis, Hugh Evander, "Some Conflicting Decisions of the United States Supreme Court" (1927). Articles by Maurer Faculty. 1247.

https://www.repository.law.indiana.edu/facpub/1247

This Article is brought to you for free and open access by the Faculty Scholarship at Digital Repository @ Maurer Law. It has been accepted for inclusion in Articles by Maurer Faculty by an authorized administrator of Digital Repository@Maurer Law. For more information, please contact rvaughan@indiana.edu.

\section{$\Psi$}

LAW LIBRARY

INDIANA UNIVERSITY Maurer School of Law
Bloomington 


\section{VIRGINIA \\ LAW REVIEW}

Vol. XIII.

JANUARY, 1927

No. 3

\section{SOME CONFLICTING DECISIONS OF THE LNITED STATES SUPREME COL'T'.}

W H.AT is Constitutional Law in the Lnited States, and how has it come to be what it is? Is it judge-made law or en acted law? Is the Lnited States Constitution the document which was made by the drafters of the Constitution and its Amendments, or the document which Iias been made by the S!!preme Court in interpreting what the drafters did and filling in the interstices left by the drafters? If our Federal Constitutional Law is in part or wholly judge-made law, what has been the nature of the judicial process? Has it been analytical, historical, or philosophical, or a combination of all three? Have the justices of the Supreme Court strictly adhered to precedlents on the rule of stare decisis, or have they treated precedents as mere hypothetical conclusions to be alsandoned later if proven false after the test of further experience? If prior decisions have been disregarded or overruled. has it been because of a change in the personnel of the bench, or because of a change in the views of the justices, or because of a change in social conditions? Can our constitutional history be divided into different periods with distinct characteristics or has it been one long period? Has there been growth and development in our Constitutional Law, or merely change? Is our Constitutional I all better or worse today than it was in 1789?

These, among other, questions concerning our Constitutional

a In order to economize on space and not to make this article unduly long. the statement of the facts of the cases has been omitted. Perhaps it is not too much to expect that those interested enough in this article to read it will be sufficiently familiar with Constitutional Law and the decisions of the United States Supreme Court, either to recall the specific operative facts in the various decisions referred to or have enough general background to supply them or to understand the discussion without them.-The Aluthor. 
Law and history, will occur to any student, teacher or practitioner who is interested in the work of our-Supreme Court. The only way to find a satisfactory answer to such questions is by an examination of the work of the Supreme Court as found in its published decisions. This study is an undertaking to make such an examination. In this article, however, no attempt will be made to examine all the decisions of the Supreme Court, because it is believed that such an attempt would be as unnecessary as it would be impossible. Only the conflicting but all the most inportant decisions of this sort will be examined. Some of the questions could be answered by an examination of other than conflicting decisions and most of these are of cumulative importance. ${ }^{1}$ let most of the questions could not be answered by an examination of non-conflicting decisions, and all of them can be answered by an examination of the conflicting decisions. As conflicting decisions we shall include both cases in conflict because a later overrules an earlier, and cases in conflict because their doctrines cannot be reconciled, or because a doctrine of one is qualified or modified by another. We shall, therefore, undertake to study Some Conflicting Decisions of the United States Supreme Court.

With this end in riew let us examine first, some decisions of the Supreme Court upon that provision of the United States Constitution which provides: "No state shall pass any law impairing the obligation of contracts." 2

In the case of Fletcher v. Peck. ${ }^{3}$ in an opinion by John Marshall, the court decided that grants (executed contracts) are included within the protection of the Constitution, in spite of the fact that the Constitution forbids the impairment only of the obligation of contracts which is supposed to be executory: and in the Dartmouth College Case, ${ }^{4}$ in another opinion written by John Marshall. the court held that a corporate charter of a charitalsle corporation is not only such a contract, rather than a mere law which can be repealed by subsequent legislation, ${ }^{5}$ so that its

\footnotetext{
'See incidental references infra.

2 Art. I, Sec. 10 .

× 6 Cranch, 87 (1810).

- 4 Wheat. 518 (1819)

- Cf. Wisconsin Co. v. Powers. 191 U. S. 379 (1903).
} 
obligation is impaired by a subsequent lail of a state, but also that its obligation is impaired though the state passes its law in the exercise of the police power, or taxation, or eminent domain. At least this was the construction put upon the Dartmouth College Case by the cases which immediately followed it. and these cases also uniformly accepted the proposition that its cloctrine was applicable to all kinds of private business corporations. ${ }^{6}$ let the courts have always held that private contracts between individuals are subject to the exercise of the power of eminent domain, the power of taxation, and the police power.' The rule of the Dartmouth College Case, in protecting private corporations against political action for fifty years, had much to do with the extraordinary development of private corporations in the L'nited States. It is said that the case has leen cited more times as a judicial precedent than any other case ever decided by a court. It is probably the most celebrated of John Marshall's opinions.

Is the Dartmouth College Case still law or are there sulbsequent cases in conflict with it which either overrule it or modify it?

In the case of Charles Rizer Bridgi $v$. II'arron Bridge s the Supreme Court limited the doctrine of the Dartmouth College Case by a rule of strict construction. so that if a charter was poorly drawn it did not amount to much, but the court dicl not directly overrule the Dartmouth College Casc. The opinion in the Charles Rizer Bridge case was written by Chief Justice Taney, after he had succeeded Chief Justice Marshall and after Justices Story and Thompson were the only two of the old court left, and it has been followed by nany subsequent decisions. ${ }^{9}$

Apparently the decision in the case of Charles Rivir Bridge v. Warren Bridge, rather than the decision in the Dartmouth College Case, met with general favor with the public. but the public evidently thought that Chief Justice Taner's opinion had not given it sufficient protection. for it began, in constitutions and

- Bridge Pro. v. Hoboken Co., 1 Wall. 116 (1864): Piqua Bank r. Knuop. 16 How. 369 (1853).

= Manigault v. Springs, 199 U. S. 473 (1905) : Mlum v. Illinnis. 94 L'. S 113 (1876).

" 11 Pet. 420 (1837).

"Knoxvilte Water Co. v. Knoxville. 200 L. S. 22 (1906): Stein v. Bienville Water Co., 141 U. S. 67 (1891); Fertilizer Co. v. Hyde Park, 97 L'. S. 659 (1878); supra note 6 . 
statutes, to limit still further the doctrine of the Dartmourh Collegc Case by forlbidding the grant of irrevocable charters, and reserving the power to alter or repeal them: and the Supreme Court held that such limitations were valid on the theory that they were a part of the obligation of the contract so that the repeal or alteration slid not impair it, and consequently again indirectly modified the doctrine announced by Marshall. ${ }^{10}$

Finally the Supreme Court in a long series of decisions gradually came to a position where it directly modified the doctrine announced by Marshall and his immediate successors. Dissenting judges had always contended that a state could not abrogate its sovereign powers of eminent domain, taxation, and police, and that the Dartmouth College Casc should have so held. ${ }^{11}$ In the eminent domain cases which came before the Supreme Court the doctrine of the dissenting judges prevailed and the court held that charters are subject to the exercise of this sovereign power. ${ }^{12}$ Then, after the personnel of the bench had again been changed, as it had been in the time of Chief Justice Taney, and the dissenting Judge Miller had been joined by Chief Justice Waite, Harlan and others who agreed with him, the court. in a series of difficult cases which came before it. began to hold that charters were subject to the exercise of the police power, first. as to public morals. ${ }^{13}$ then as to public health, ${ }^{14}$ then as to public safety. ${ }^{15}$ and finally as to economic social interests. ${ }^{16}$ These cases did not overrule the Dartmouth College Case, at least so far as it held that a charter is a contract, but they did put important limitations upon its doctrine.

However the Supreme Court has not applied its later doctrine to the regulation of the rates of public utilities, ${ }^{17}$ although the

\footnotetext{
${ }^{30}$ Greenwood v. Freight Co., 105 U. S. 13 (1882).

"Washington Univ. v. Rouse, 8 Wal!. 439 (1869); Piqua Bank v. Knoop, supra note 6: Trustees of Dartmouth College v. Woodward, supra note 4.

"Long Island Water Co. v. Brooklyn, 166 U. S. 185 (1897); West Ridge Bridge Co. v. Dix, 6 How. 507 (1848).

"Stone v. Mississippi, 101 U. S. 814 (1879).

" Butchers, etc. Co. v. Crescent City Co., 111 U. S. 746 (1883).

15 Texas, etc., Co. v. Miller. 221 U. S. 408 (1911) ; New Orleans v. Louisiana Light Co.. 115 U. S. 650 (1885).

${ }^{10}$ Illinois Cent. Ry. Co. v. Illinois, 146 U. S. 387 (1892).

: Columbus, etc., Co. v. Columbus, 249 U. S. 399 (1919); Vicksburg v. Vicksburg Waterworks Co., 206 U. S. 496 (1907); Cleveland v. Cleveland
} 
power to fix such rates is recognized as a part of the police power, ${ }^{18}$ and it has steadfastly refused to apply its later doctrine to taxation cases. ${ }^{19}$ This makes the taxation cases and the rate cases contra to the eminent domain cases, and all the police power cases, except the rate cases, but in accord with the Dartmouth College Case; and makes the eminent don ${ }^{-i n}$ cases and all the police power cases, except the rate cases, in conflict with the Dartmouth College Case.

It will probably be generally agreed today that the Dartmouth College Case was not correctly decided, and that it should have held either that a charter of a corporation is not a contract at all but a law or that it is a contract but subject to the exercise of the sovereign powers of police, taxation, and eminent domain. The latter view has become the modern view of the Supreme Court and the Dartmouth College Case has been corrected accordingly except as to taxation and rates. These exceptions are indefensible and doubtless in the course of time will be eliminated by the Supreme Court so as to harmonize the taxation and rate cases with the police power and eminent domain cases. But even now, while it would be incorrect to say that the Dartmouth College Case has been overruled, because it continues to be doctrine so far as type it made a charter of a corporation a contract, yet, it would not be accurate to say that it is still law, because it is no longer doctrine so far as it freed such contracts from the exercise of the police power and the power of eminent domain.

As a result of our study of the cases decided on the provision against impairing the obligation of contracts, we see that we have at the very outset both an illustration of judge-made laws by means of interpretation, and an illustration of a judicial precedent, which has been treated as a hypothetical conclusion to be atandoned later. In making this change the court invoked the philosophical or sociclogical process, but in this case a change in the personnel of the bench and changing social conditions had

City Ry., 194 U. S. 517 (1904) ; Detroit v. Detroit Citizens Ry.. 184 U. S. 368 (1902).

2s Munn v. Illinois, supra note 7.

19 Lake Superior, etc., Mines v. Lord. 46 Sup. Ct. 627 (1926) : Roberts, etc.. Co. v. Emerson, 46 Sup. Ct. 375 (1926); Washington Univ. v. Rouse. supra note 11 ; Piqua Bank v. Knoop, supra note 6. 
more to do with the change of the law than a change in the views of the justices. The result has been in the line of progress.

Next, let us examine some of the cases tupon the subject of our dual form of goveriment.

It now seems to be agreed that the framers of our Constitution made a dual form of government one of the chief characteristics of our Constitution. This means that the Federal Government was neither a league of nations, nor a government in which the states were mere administrative units, but a federation of nations. The nation was sovereign within its sphere and the states were sorereign within their spheres. But the Constitution did not expressly say this. In fact neither the extreme federalists nor the extreme states rights men believed it. The question was not settled until it was settled by Chief Justice Marshall in his great opinions in the cases of $M I C C$ ullough v. Maryland ${ }^{20}$ and Gibbons v. Ogden. ${ }^{21}$ In these cases he moved all doubt as to whether the Constitution was a constitution or a compact and yet did not destroy the supremacy of the states within their field of reserved powers. Thereby he made the Lnion a commonwealth of commonwealths, a nation of nations or states. This is another illustration, therefore, of judge-macte law. Marshall made this government a clual form of governntent through the analvtical process by means of interpretation.

Have Marshall's decisions upon this question been followed as precedents, or treated as hypothetical conclusions?

Marshall himself tended perhaps to break down his own doctrine of a clual form of government by deciding in favor of the leeleral Government whenever there was a question as to whether. a power was a state or federal power. In the great case of Cohens r. Iirginia. ${ }^{22}$ by establishing the appellate jurisdiction of the Supreme Court over the courts of the states, he practically made the state courts inferior courts in the federal systen. In his original package clecision $^{23}$ he further extended the power of the Federal

"v 4 Wheat. 306 (1819).

$" 9$ Wheat. 1 (1824).

$=6$ Wheat. $264(1821)$. For a recent case which. by requiring state courts to enforce rights created by act of Congress, further tended to make the state courts part of the icderal system, sce Sccond Employers' L,iability Cascs, 223 U. S. 1 (1912).

$\Rightarrow$ Brown v. Maryland, 12 Wheat. 419 (1829). 
Government at the expense of the states. His cloctrine of the implied powers of the Federal Government ${ }^{24}$ also inevitably tended in this same direction.

With the change in the personnel of the bench which came after the appointment of Clief Justice 'Taney the states rights people expected to see Marshall's position in regard to our form of government overthrown in favor of the states, yet Taney never departed from the position that our government is a chual form of government, and he rendered a number of opinions which vindicated the supremacy of the Federal Government within its sphere. ${ }^{25}$ The situation continued thus up to the time of the Civil War. After the Civil War the fecleralists, especially those with corporate interests. hoped, under the privileges and immunities and due process clauses, to see overthrown in favor of the nation Marshall's position in regard to our dual form of government, but Justice Miller and the other majority members of the Supreme Court doomed them to disappointment in their decisions in the Slaughterhouse Cases ${ }^{26}$ and the Cir'il Rights Cases.s.

At last, however, under a reconstituted court and the leadership of Justice Field, who had formerly been a dissenting justice, the Supreme Court began, and their successors have continued to enlarge the powers of the Federal Government at the expense of the states in a way to seriously threaten the doctrine that this is a chal form of government. The Supreme Court extended the inhilsition upon state action in the clue process clause, not only to the protection of the negroes but also to the protection of natural persons, in matters of substance ${ }^{28}$ as well as of legal procedure, ${ }^{2 !}$

* Gibbons v. Ogden, supra note 21: McCullough v. Marỵland, supra note 20.

$=$ E.r parte Wells, 18 How. 307 (1855) ; Prigg v. Commonwealth of Pa., 16 Pèt. 539, 626 (1842).

$\Rightarrow 16$ Wall. $36(1873)$.

$=109$ L. S. 3 (1883).

$=$ Wolff v. Ct. oi Industral Relations, 202 C. S. 522. 267 L'. S. 552 (1923): Meyer v. Nebraska, 262 L. S. 390 (1923) : Minimum Wage Brd. r. Children's Hospital, 261 L. S. 525 (1923) : United Mine llorkers v. Coronado. etc., Co., 259 L. S. 344 (1922): Truax v. Corrigan, 257 L. S. 312 (1921) : Lockner v. New York, 198 C. S. 45 (1905): Allgeyer v. Louisiana. 165 L. S. 578 (1897): Reagan v. Farmers Loan \& Trust Co., 154 L. S. 362 (1894); (Chicago, etc. Ry. Co. v. Minnesota, etc., Com., 134 C. S. 418 (1890) : Hurtado r. Caliiornia, I10 L. S. 516 (1884).

$\Rightarrow$ Davidson v. New Orleans, 96 C. S. 97 (1878): Murray v. Hobuken I. it I. Co., 18 How. 272 (1855). 
and even to the protection of corporations in the matter of property rights." so as to estallish the supremacy of the national government over the states in all these important matters. It extended the power of the Federal Government over interstate comnerce until it eliminated all jurisdiction of the states over even intrastate commerce in some important lines of business. ${ }^{31}$ In I'eazie Bank v. Finno 32 it held that Congress could tax the notes of state banks so as to destroy their circulation, although it had held in MICCullough v. Maryland ${ }^{33}$ that a state legislature could not tax the notes of a federal bank. In South Carolina v. United States $^{34}$ it held that the Lnited States could tax the selling of liquor though done by the state of South Carolina; but in North Dakota. v. Hanson ${ }^{35}$ it held that North Dakota could not require the holders of a federal retail liquor license to print notice thereof, post an affidavit of publication and pay a fee, and in $V$ an Brocklin v. Tennessec ${ }^{36}$ it held that the State of Tennessee could not tax land bought by the United States on the sale of land for non-payment of United States taxes. In St. Louis v. W. U. Tel. $C 0 .^{37}$ and in United States v. Gettysburg Elec. Ry. Co ${ }^{38}$ it held that the United States could condemn state property for federal purposes; but in Utah P. E L. Co. v. United States ${ }^{30}$ it held that a state could not condemn federal land for state purposes. It has extended the scope of the postal powers, ${ }^{40}$ the treaty powers ${ }^{41}$ and the war powers ${ }^{42}$ so as to threaten still further the doctrine of the dual form of government. In the National Prohibition Cases $^{43}$ the court held plainly that there is nothing in the Con-

${ }^{30}$ Covington. etc., Co. v. Sanford, 164 U. S. 578 (1896); Minneapolis Ry. v. Beckwith, 129 U. S. 26 (1889).

* Commission v. Railway, 257 U. S. 563 (1922); Shreveport Case; 234 U. S. 342 (1914) ; Minnesota Rate Cases, 230 U. S. 352 (1913).

$=8$ Wall. 533 (1869).

Supra note 20.

34 199 U. S. 437 (1905).

ss 215 U. S. 515 (1910).

so 117 U. S. 151 (1886).

$=148$ U. S. 92 (1893).

I* 160 U. S. 168 (1895).

30 243 U. S. 389 (1917).

10 Pensacola Tel. Co. v. Western Union Tel. Co., 96 U. S. 1 (1878).

"Missouri v. Holland, 252 U. S. 416 (1920).

$=$ Miller v. United States, 11 Wall. 268 (1870).

.253 U. S. 550 (1920). 
stitution to prevent the absolute destruction of state sovereignty. These decisions have worked a profound change in the character of our dual form of government, if they have not entirely destroyed it. The states are certainly in the process of being reduced to the status of administrative units.

It is hard to believe, after reading such decisions as those referred to in the paragraph immediately preceding. that the decisions of John Marshall have been followed as precedents. The constitutional principles which he first announced as to our dual form of government have been modified and qualified and the sphere of the Federal Government has rapidly been enlarged at the expense of the states until now there is only one conclusion to which we can come and that is that the recent decisions of the Supreme Court upon this subject are in conflict with those of John Marshall. His decisions were only hypothetical conclusions and they have been abandoned. Whether or not the recent decisions are the better depends upon our political philosophy, but so far as the growth of federalism has kept step with the growth of business the writer is of the opinion that they are the better. It would seem, however, in this instance that an important factor in this constitutional change. or development, has been the personnel of the bench.

Next, we will consider some decisions of the Supreme Court on the so-called interstate conmerce clause, which gives Congress the power "to regulate commerce with foreign nations. and among the several states, and with the Indian tribes." 44

The case of Gibbons v. Ogden ${ }^{4}$ is the one with which to begin for a starting point in the discussion of the commerce clause. In this case Webster made his greatest argument. and the decision in this case Beveridge says is Marshall's most important decision. It established in a liberal sense the power of the United States against the states over interstate commerce. It gave a definition of commerce, yet not one clear enough to prevent later conflicting decisions on the same question. It explained when commerce commenced and when it ceased to be interstate, yet not in such a way as to prevent later conflicting decisions on this question. It left open the question of who had the power to regulate

"U. S. Coxst.. Art. I. Sec. 8, clause 3.

ts Supra note 21 . 
interstate commerce. Whether or not the states had concurrent power to regulate it in the alssence of federal action was not decided because on this question Congress had legislated. Whether after congressional action the states still had concurrent power of regulation so long as its legislation was not in conflict with federal legislation, or only an incidental power to affect interstate commerce in the exercise of the general police power, was left undecided, although there was a strong intimation that it was the latter. It did not decide whether or not a state could tax interstate commerce.

In Gibbons v. Ogden, Marshall said that commerce included both traffic and commercial intercourse and therefore navigation. In New York v. Miln ${ }^{\text {t6 }}$ the Supreme Court declared that goods were the sulject of commerce but persons were not, but in Glocester Ferry Co. v. Pennsylirania ${ }^{47}$ and in Hoke v. United States ${ }^{48}$ it held that conmerce included the transportation of persons as much as property, and in Covington Bridge Co. v. Kentucky ${ }^{49}$ it held that it included the passing and repassing of people on a bridge. In Pensacola Tel. Co. v. Western Union Tel. Co. ${ }^{50}$ the Supreme Court held that sending telegrams, in International Text Book Co. v. Pigg ${ }^{51}$ it held that sending correspondence school information and paraphernalia, and in the Lottery Case ${ }^{52}$ it held that sending lottery tickets were all subjects of commerce, although in the earlier case of Paul v. I'irginia ${ }^{53}$ it had held that making contracts of insurance, and in the case of Blumenstock, etc., -Agency v. Curtis Pub. Co. ${ }^{54}$ it held that making contracts for advertising were not commerce. Vague as was Marshall's definition, it is evident that the Supreme Court has since his time enlarged upon his definition and that the distinctions now made between conmerce and what is not commerce are either instances of conflicting decisions or so fine that they are practically incomprehensible.

\footnotetext{
11 Pet. 102 (1837).

* 114 U. S. 196 (1885).

" 227 U. S. 308 (1913).

*: 154 .U. S. 204 (1894).

- Supra note 40.

$\Rightarrow 217$ U. S. 91 (1910).

$\because 188$ L. S. 321 (1903).

$=8$ Wall. 168 (1868).

$\because 252$ U. S. 436 (1920).
} 
As to when commerce becomes interstate Marshall said, "Is "It may very properly be restricted to that commerce which concerns more states than one. . . . . Commerce among the states must, of necessity, be comnierce with the states. . . . The power of Congress must be exercised within the territorial jurisdiction of the several states," but it has been difficult for sul)sequent cases to determine where interstate commerce begins and where it ends. The Supreme Court has held that interstate commerce does not begin with the production or manufacture of goods, even though definitely destined for transportation to another state, ${ }^{56}$ nor with the machines of such production or manmfacture, ${ }^{57}$ nor with the movement of goods to the point of shipment so long as the goods are not actually clelivered to the conmon carrier for shipment $:^{-58}$ yet in the case of Dahnke-lWalker.$I I$. Co. v. Bondurant ${ }^{59}$ it held that interstate commerce between Kentucky and Tennessee began with the purchase of wheat in Kentucky for shipment into Tennessee, and in the case of L.cmpkc v. Farmers' Grain Co. ${ }^{00}$ it held that interstate commerce began with the deposit of wheat in grain elevators though not yet bought (and though under state decisions the transaction between the depositor and the elevator was a bailment), on the theory that the grain was usually shipped to Minneapolis. Minnesota. If these decisions are not in conflict, they draw a line which it is almost inpossible to see. Marshall in the case of Broz'n v. Maryland ${ }^{61}$ held that foreign commerce does not end until after the goods have been taken from the original package. In the case of Austii v. Tennessee $^{62}$ the Supreme Court extended this rule to interstate commerce so far as concerns regulation, but in the case of Brozen v. Houston ${ }^{63}$ it refused to go so far as concerns taxation. These cases clearly cannot be reconciled.

As to who has the power to regulate interstate commerce,

ss Gibbons v. Ogden, supra note 21.

so Kidd v. Pearson, 128 U. S. 1 (1888).

s: Crescent Cotton Oil Co. v. Mississippi, 257 L. S. 129 (1921).

${ }^{38}$ Coe v. Errol, 110 U. S. 517 (1886).

s5 257 U. S. 282 (1921).

$\infty 258$ U. S. 50 (1922).

- Supra note 23.

f 179 U. S. 343 (1900).

* 114 U. S. 622 (1885). 
Webster had argued that the federal power, was exclusive and Marshall seemed in Gibbons v. Ogden to acquiesce in this argument, yet five years later in the case of Willson v. Blackbird Creck Marsh Co. ${ }^{04}$ Marshall took the position that the power of the states was concurrent while the congressional power lay dormant. This remained federal doctrine for twenty-five years or so. ${ }^{65}$ In the case of Cooley v. Board of Port Wardens ${ }^{86}$ the Supreme Court introduced the distinction between the subjects of interstate commerce which are purely national in scope. or admit of only one uniform plan of regulation. and all other subjects, and held that Congress had exclusive jurisdiction of the former even before legislation. and that the states had concurrent jurisdiction over the latter in the absence of congressional legislation. This distinction was followed for some time. ${ }^{67}$ In recent times we have hearl less about the concurrent power of the states and more about what Congress may do in regulating intrastate. commerce as inciclental to interstate conmerce. ${ }^{68}$ and more about what the states may (lo in the exercise of their police power though it incidentally affects interstate commerce." ${ }^{\text {"9 }}$ Undoubtedly the better view would be that the power of Congress over interstate commerce is exclusive, and that where intrastate and interstate business are so interwoven that they cannot be separated that Congress may regulate both, ${ }^{70}$ but that the states have a general police power under which they may regulate interstate commerce incidentally so long as their statutes do not conflict with federal statutes upon the same subject. However, it cannot be said that this is yet federal law, because the earlier cases with reference to the concurrent power of the states have not, been overruled. They still stand simply as conflicting cases.

. Is a proof of the conflict involved in these cases attention is

a 2 Pet. 245 (1829).

¿ Gilman v. Philadelphia, 3 Wall. 713 (1866): License Cases, 5 How. 504 (1847).

* 12 How. 299 (1851).

"Wabash. ctc. Co. v. Illinois, 118 U. S. 557 (1886); Hall v. De Cuir, 95 U. S. 485 (1878): Welton v. Missouri. 91 U. S. 275 (1875).

a Shreveport Case. supra note 31; Leisy v. Hardin. 135 U. S. 100 (1890).

* Minnesota Rate Cases, supra note 31; Plumlcy v. Massachusetts, 155 U.

S. 461 (1894).

:o Shreveport Case, supra note 31. 
called to the License .Cases, ${ }^{71}$ decided in 1847 , where the Supreme Court held that a New Hampshire license law was valid as applied to liquors in the original package under the concurrent power theory; to the case of Leisy v. Hardin, ${ }^{72}$ decided in 1890 , where the Supreme Court held that an Iowa liquor law was unconstitutional as applied to liquors in the original package because a burden on interstate commerce both as to sale and as to transportation, evidently on the theory that here was a subject national in character, and to the case of Plumley v. Massachusetts, ${ }^{73}$ decided in 1894, where the Supreme Court upheld a Massachusetts statute on the subject of colored oleomargarine as applied to interstate original packages on the theory that it was a proper exercise of the police power. It is hard to harmonize the case of Leisy v. Hardin with either of the other cases. The Supreme Court pretended to reconcile the Plumley and Leisy cases. by showing that in the Plumley Case there was the fact of "coloring in oleomargarine," while in the Leisy Case there was no fact of "coloring", but admitted the License Case was overthrown. The writer prefers the explanation that they are all in conflict and that the reason for the conflict is the change in the personnel of the bench. Leisy v. Hardin was a five to three decision. and Plumley v. Massachusetts a five to four decision. Not one of the judges who participated in the decision of the License Cases was on the bench at the time of the decision in the Leisy Case. Only two of the majority judges in the Leisy Case. Fuller and Field, were on the bench at the time of the decision in the Flumley Case, and one of the dissenting judges in the Leisy Case wrote the opinion in the Plumley' Case.

Again, the Supreme Court, in the case of Heisler v. Thomas Colliery $\mathrm{Co} .{ }^{74}$ held that a tax on anthracite coal by Pennsylvania was not an interference with interstate commerce though most of the coal is shipped out of the state, but in Pennsyla'ania v. IVest Virginia ${ }^{75}$ it held that the enforced withdrawal by West Virginia of natural gas produced therein for the benefit of local consumers

\footnotetext{
"Supra note 65.

:Supra note 68.

:3 Supra note 69.

i4 260 U. S. 245 (1922).

:s 262 U. S. 553 (1923).
} 
is an "interference with interstate commerce . . . forbidden by the Constitution." And in Allen v. Pullman's Palace Car Co. ${ }^{\text {i6 }}$ the Supreme Court held that a tax of a definite sum levied on an interstate corporation for the privilege of doing intrastate business was not an interference with interstate business because the interstate carrier could discontinue its intrastate business, but in $V^{\prime} e s t . U$. Tel. Co. v. Kansas ${ }^{77}$ it held that a tax of a given per cent on the entire capital of an interstate corporation for the privilege of doing intrastate business was an interference with interstate business, though if the corporation could discontinue its intrastate business in the first case it would seem that it ought to be able to do so in the second case, and if the state is master of its local business in one case it ought to be in the other.

The power of regulating interstate commerce which has been delegated to Congress is a police power, and in the exercise of this power apparently the Supreme Court has held that anything which may be prohibited by the states under their police power, may. when it is the subiect of interstate commerce, be prohibited by Congress. Accordingly, it has held constitutional a statute limiting the hours of service of employees of railroads engaged in interstate commerce, ${ }^{78}$ an employers' liability act imposing a greater liability than at common law upon railroads engaged in interstate commerce for injury or death of any employee engaged in such commerce, ${ }^{79}$ a statute making it a criminal offense to transport lottery tickets in interstate commerce, ${ }^{80}$ a statute against the transportation of women and girls in interstate commerce for immoral purposes, ${ }^{81}$ a pure food and drugs act, ${ }^{82}$ and an act to punish the counterfeiting and use of fictitious interstate bills of lading even though they relate to no actual or contemplated commerce; ${ }^{83}$ but by a majority of five to four it held unconstitutional a federal child labor law which prohibited the transportation in interstate

\footnotetext{
ic 191 U. S. 197 (1903).

"216 U. S. 1 (1910).

78 Baltimore, etc., Co. v. Interstate Com. Com., 221 U. S. 612 (1911).

"Second Employers' Liability Cases,. 223 U. S. 1 (1912).

sottery Case, supra note 52.

" Hoke v. United States, supra note 48.

* McDermott v. Wisconsin, 228 U. S. 115 (1913); Hipolite Egg .Co. v. United States, 220 U. S. 45 (1911).

N United States v. Ferger, 250 U. S. 199 (1919).
} 
commerce of the products of mines in which children uncler sixteen were employed, and the products of manufacturing estal)lishments in which children under fourteen were employed, or in which children under sixteen were allowed to work more than eight hours a day, or before six in the morning or after seren at night, on the theory that this was not a regulation of interstate commerce but of mining and manufacturing. ${ }^{84}$ It is hard to see why the same objection cannot be made to the lottery. white slave. and the food and drug acts, and the decision came as a surprise to the profession.

In the case of Conzeay v. Taylor's Exccutor, ${ }^{85}$ the Supreme Court took the position that a ferry was so local in nature tiat a state had the exclusive power to regulate it though it plied on a river which was the boundary between two states. but this doctrine was gradually modified by the decisions of Gloucester Forry Co. v. Pennsylz'ania, ${ }^{86}$ Covington v. Kentucley ${ }^{\mathrm{s}}$ Port Richmond Ferry v. Hudson Co., ${ }^{88}$ and Sault St. Maric v. In. Trans. Co.s: until little is left of it and ferries have more and more heen made subject to regulation by Congress.

It seems apparent that the decisions of the United States Supreme Court upon the commerce clause are in hopeless conflict. Not only is it impossible to harmonize the late cases with the early cases, but it is impossible to harmonize the late cases. There has been in the decisions a general trend in the direction of the enlargement of the powers of the Federal Government: 1)ut it cannot yet be said that there are any consistent, well-settled principles as to what is commerce, when it is interstate. Who has the power of regulation over it, or what may le done in the regulation of it. Most of the law in this connection is judge-made law. although it has been made by the process of interpretation of an express power granted to the Federal Govermment. Most of the conflicts are probably due to changes in the persomnel of the bench. and the consequent introduction into the law of the personal views of the justices or the views of the tinies in which they lived.

\footnotetext{
* Hammer v. Dagenhart, 247 U. S. 251 (1918).

* 1 Black, 603 (1862).

so 114 U. S. 196 (1884).

" 154 U. S. 204 (1894).

- 234 U. S. 324 (1913).

234. U. S. 349 (1913).
} 
Next, let us turn our attention to some federal tax decisions of the United States Supreme Court.

The Constitution provides that "No capitation or direct tax shall be laid unless in proportion to the census or enumeration hereinbefore directed to be taken," ${ }^{80}$ and it therefore becomes important to know what is a direct tax. Hamilton was of the opinion that the words meant capitation taxes, taxes on land, and general taxes on all the property of individuals, but the Supreme Court in the early case of Hylton v. United States ${ }^{31}$ held that taxes on specific kinds of personal property (carriages) and on occupations were excise and not direct taxes, and suggested that the only direct taxes were taxes on land and capitation taxes, on the theory that the determining. factor was the possibility of apportionment. In Scholey v. Rew ${ }^{92}$ the Supreme Court held that a tax on succession to real estate was not a direct tax but an excise tax on the privilege of taking by inheritance. In Springer v. United States ${ }^{93}$ the Supreme Court by a unanimous decision held that the Civil War income tax was not a direct tax but an excise $\operatorname{tax}$ on the theory that direct taxes were "only capitation taxes and taxes on real estate." But in Pollock v. Farmers' L. \& T. $\mathrm{Co}^{94}$ a five to four majority of the court presided over by Chief Justice Fuller decided that a tax upon personal property or upon the income therefrom is a direct tax, and thereby in effect overruled both the Springer v. United States and Hylton v. United States cases. The result of this decision was the passage of the Sixteenth Amendment, after which the Supreme Court said in Brushaber v. Union Pac. R. $R .^{95}$ that all federal income taxes are now excises, but in spite thereof, in Eisner v. Macomber, ${ }^{96}$ within four years a majority of the same court held in another five to four decision that an income tax on stock dividends is a direct tax. After this decision in the Pollock case, it was thought that the Supreme Court would hold that a tax on the succession to personal property would be held to be a direct tax, since the court

\footnotetext{
${ }^{\infty}$ U. S. Const., Art. I, Sec. 9, clause 4.

"2 3 Dallas, 171 (1796).

23 Wall. 331 (1874).

102 U. S. 586 (1880).

* 157 U. S. 429,158 U. S. 601 (1895).

2240 U. S. 1 (1916)

252 U. S. 189 (1920).
} 
had said in the Scholey case that an inheritance tax was not distinguishable from an incone tax, but when the question was presented to the court in the case of Knoulton v. Moore ${ }^{97}$ the court discovered that an inheritance tax was an excise rather than a direct tax and quite distinguishable from an income tax. How are the decisions in the Eisner and Pollock cases to be accounted for? The obvious answer is a change in the personnel of the bench. But what were the new justices trying to accomplish by their decisions? Very clearly they were not accomplishing certainty in the law. There was no moral interest which they were trying to protect. Apparently their decisions were only an application of the legal philosophy of the Period of Maturity which emphasized property and contract and freedom from legal control.

Can taxation, which clearly has for its purpose the raising of revenue, also be used for the purpose of regulation? Here again the decisions of the United States Supreme Court are in conflict. In some it has said "yes," while in others it has said "no." In Veasie Bank v. Fenno ${ }^{98}$ the Supreme Court upheld a tax upon the notes of state banks although prohibitive and therefore evidently for the purpose of regulation. In the Head Money Cases $^{99}$ it upheld a tax of fifty cents levied upon the owners of vessels for every passenger brought from a foreign port, though "the power exercised in this instance is not the taxing power" but a "mere incident of the regulation of commerce." A tariff enacted purely for protection and not for revenue would have to be upheld, if at all, upon the same theory. In McCray v. United States ${ }^{100}$ it upheld a tax of ten cents a pound upon oleomargarine colored to look like butter as a legitimate subject of an excise tax and held that the purpose of Congress was irrelevant, and that if a power was conferred it made no difference if its exercise "was either unwise, or unjust," or even for an "unlawful purpose." In the last case it should be noted that a tax, though for purposes of regulation, was upheld though not connected with any other power given to Congress. But in the case of Bailey v. Dre.tel

" 178 U. S. 41 (1900).

8 Wall. 533 (1869).

- 112 U. S. 580 (1884).

${ }^{100} 195$ U. S. 27 (1903). 
Furn. Co. ${ }^{101}$ it declared unconstitutional a federal tax of ten per cent of the net profits received for the sale of products of establishments employing child labor, on the ground that the tax was "manifestly intended to regulate the employment of child labora matter reserved to the states by the Tenth Amendment-and not a tax;" and in the case of Trusler v. Crooks ${ }^{102}$ it declared unconstitutional a tax on the privilege or option for a contract either for the purchase or sale of grain, on the ground that it was a penalty and not a tax. If the last two cases are good decisions it is hard to see how the McCray case at all events can be a good decision. It would seem as though it should have been overruled in the Bailey case, but it has been left standing as a conflicting decision, so that we have one principle of constitutional law for oleomargarine and another principle for child labor in the matter of the use of the power of taxation for purposes of regulation. In the Bailey case, it is true, the court distinguished the Child Labor Act from the Oleomargarine Act in that the former showed on its face that it was a regulation while the latter did not. This distinction is not entirely convincing, but we should be glad that the court did not attempt to distinguish them on the basis that the oleomargarine was "colored", while the children were not "colored." The principle of the child labor decision also would apply to a protective tariff which shows on its face that it is for the purpose of regulation and not for revenue. Some industrious democrat ought to give a republican Supreme Court an opportunity to distinguish between a child labor law and a protective tariff of the sort referred to.

Another instance of conflict in the decisions of the United States Supreme Court is found in connection with the question of whether or not there is a federal common law. The justices of the Supreme Court, when trying cases on circuit, at first held that there was a federal common law of crimes and tried and punished people for violations thereof without the support of any federal statute, ${ }^{103}$ but Justice Samuel Chase held the opposite view while

\footnotetext{
${ }^{101} 259$ U. S. 20 (1922).

${ }^{102} 46$ Sup. Ct. 165 (1926).

100 William's Case, Fed. Cas. 17,708 (1799); United States v. Warrall, 2 Dallas, 384 (1798); United States v. Ravara, 2 Dallas, 297 (1793); Henfield's Case, Fed. Cas. .6360 (1793).
} 
on circuit in the case of United States $v$. $/ T^{2}$ arrall, ${ }^{104}$ and in the case of United States v. Hudson, ${ }^{105}$ Chase's view was acted upon by the Supreme Court. Since the latter decision it has been consistently held by the Supreme Court that there is no federal common law of crimes, ${ }^{106}$ but the Supreme Court has found that, in spite of the fact that the Constitution gives Congress the express power to punish as crimes only "piracies and felonies committed on the high seas," "offenses against the law of nations," "treason," and "counterfeiting the securities and current coin of the United States," 107 it gives Congress the implied power to punish "all crinies and offenses against the United States whether committed within one of the states of the union or within territory over which Congress has exclusive jurisdiction," ${ }^{108}$ so that the Federal Government, with this gift of federal statutory criminal law, will apparently get along very well without any federal common law of crimes. ${ }^{108}$ Is there a civil common law of the United States? The Supreme Court apparently at first took the position that there is not. The Judiciary Act of 1789 required the fecleral courts to apply "the laws of the several states" "as rules of decision in trials at common law," except where the Constitution. treaties, or statutes of the United States otherwise provicle. In the case of Jackson v. Clew, ${ }^{110}$ the court held, in a case involving real property, that it was bound to follow the local law whether it grew out of a statute or out of the common law. At this time the court evidently took the position that when parties got into the federal courts on the ground of diversity of citizenship, and the federal courts had to apply the common law, it must be the common law of the state where the federal court was sitting. But in the cases of Swift v. Tyson, ${ }^{111}$ Railroad v. Lockwood, ${ }^{112}$ Liverpool v. Phonix, ${ }^{113}$ and other similar cases the court confined the

\footnotetext{
10. Supra note 103.

iss 7 Cranch, 32 (1812).

106 Burdick, The Law of the Anerican Constitution, at 379.

${ }^{107}$ U. S. Const., Art. I, Sec. 8; ibid., Art. III, Sec. 3.

${ }^{100}$ Logan v. United States, 144 U. S. 263 (1891); E.r parte Seibold, 100 U. S. $371(1880)$.

${ }^{100}$ Pierce v. United States, 252 U. S. 239 (1920): Schacfer v. United States, 251 U. S. 466 (1920).

${ }^{110} 12$ Wheat. 153 (1827).

111 Pet. 1 (1842).

11: 17 Wall. 357 (1873).

${ }^{113} 129$ U. S. 397 (1889).
} 
application of the rule of the Judiciary Act of 1789 to state statutes and real property and refused to apply local common law in the field of commercial transactions and liability for torts generally, but instead applied those principles of the common law which it chose to adopt; and thereby began to develop a true, judge-made, federal, civil, common law.

In the matter of "admiralty and maritime jurisdiction" the Supreme Court at first followed the English rule which limited admiralty jurisdiction to waters where the tide ebbed and flowed. ${ }^{114}$ However, in the United States this excluded from admiralty jurisdiction the Great Lakes and our important navigable rivers, and the Supreme Court later changed its position, overruled the earlier cases, and extended the admiralty jurisdiction to all public navigable streams in the L'nited States. This was done first with reference to the Great Lakes in a notable opinion by Chief Justice Taney in the case of The Genesee Chief. ${ }^{115}$ Then it was done with reference to our great rivers, at first through a confused coupling of the admiralty jurisdiction with the power over commerce, ${ }^{116}$ but finally freed from any such notion. ${ }^{117}$ At length it was done with reference to canals and other bodies of water lying entirely within one state. ${ }^{118}$

The conflicting decisions over the questions of federal civil common law and admiralty and maritime jurisdiction can be accounted for by the explanation that the Supreme Court realized, after a time, that its earlier decisions were too narrow and not sufficiently supported by sound reasoning and social interests, and that when it came to this realization it treated them as mere hypothetical conclusions to be abandoned when proven false.

(To be continued in February Number.)

Hugh Ez'ander Willis.

Indiaxa Uxitersity Law School.

\footnotetext{
13 Orleans v. Phoebus, 11 Pet. 175 (1837); The Thomas Jefferson, 10 Wheat. 428 (1825).

"15 12 How. 443 (1852).

"10 The Montello, 11 Wall. 411 (1871); Nelson v. Leland, 22 How. 48 (1859); Allen v. Newberry, 21 How. 244 (1859); Jackson v. Steamboat Magnolia, 20 How. 296 (1858).

13 In re Garnett, 141 U. S. 1 (1891) ; Insurance Co. v. Dunham, 11 Wall.

1 (1870): The Belfast, 7 Wall. 624 (1869).

${ }^{118}$ The Robert W. Parsons, 191 U. S. 17 (1903); Ex parte Boyer, 109 U.

S. 629 (1884).
} 